\section{A CASE OF SNAKE-BITE.}

By F. B. REILly, M.R.C.S. ENG., L.R.C.P. Lond.

A COLOURED MAN twenty-five years of age was bitten on April 1st on the finger by a snake about 5 P.M. and was not seen by myself till $7 \mathrm{~A}$.M. on the following morning at the hospital. Directly after he was bitten he was cut by natives over the finger, the hand and the posterior part of the axilla, the incisions being about twenty in number and onethird of an inch in length. These evidently had bled freely and were oozing when seen. In the morning of the 2nd he appeared anxious, the pupils were dilated, and the pulse slightly accelerated and weak. His hand and forearm were much swollen, hot and painful, and the site of the bite bled freely ; fluctuation could be felt over the entire finger and was found to contain only blood. A mixture of ether and ammonia was given and hot fomentations of boracic acid were applied locally.-April 3rd : The hand and forearm are still swollen and pain has considerably increased. In the axilla was felt a large gland, acutely painful, and necessitating a pillow between the elbow and the body to keep the pressure of the arm off it. He has vomited twice to-day, the vomit each time containing bright blood. His bowels have also been opened twice and the fæces also contain blood. He complains greatly of pain in the back and aching of the limbs. His temperature is $1002^{\circ}$.- -4th: To-day he complains of pain on passing urine, and on examination it was found to be very acid and to contain blood. The quantity of urine passed in the twenty-four hours is nineteen ounces. The temperature is $99 \cdot 6^{\circ}$. - 5th : The axillary gland is smaller but still painful; he romited again to-day a quantity of blood. The urine is very dark with blood, and for the last sixteen hours he has only passed three ounces; this was examined with the microscope and found to contain only ordinary blood cells. The temperature is $1014^{\circ}$. The hand and arm are still much swollen but are gradually getting reduced in size. The tongue to-day is dry and brown, the pulse increased in frequency and weak and he seems much exhausted. The pains in the back are still present. Diuretics and stimulants were given freely, also a purge. -6th: The quantity of urine has increased considerably, the patient having passed twenty. nine ounces during the last twenty-four hours, but it still contains a large quantity of blood. To-day be is calling out at intervals of about ten minutes owing to spasmodic contraction of the muscles, those of the abdominal wall and the neck being most marked, the trapezius standing out prominently during the contraction. The axillary gland is less painful and smaller in size. The temperature is $1004^{\circ}$. -7th : To-day the patient appears worse, his skin is cold, pulse rapid and feeble, respiration hurried and shallow. The temperature is $976^{\circ}$. He complains of intense pain in the muscles of the thorax, especially the pectoral muscles. On auscultation the breath sounds and those of the heart were normal. The swelling of the forearm has nearly gone. The urine still contains a large quantity of blood, and amounts to twenty-two ounces during the twenty-four hours. The patient romited twice this morning a blackish liquid not blood) and, in spite of treatment, died from collapse at $1 \mathrm{P.M}$.

The treatment consisted principally in treating each symptom as it appeared and at the same time supporting the patient with stimulants and a nutritious liquid diet. Throughout the case no suppuration took place and the swollen hand, arm and axillary gland were getting smaller daily. The urine for the last four days contained a very large quantity of blood and this, with the other hæmorrhages, probably caused the collapse. The patient remained conscious till the end. The snake was about a yard long, with a greyish-brown back, with patches at intervals on it, and $I$ am told in appearance much like a rattlesnake, but not of that species.

Niger River, West Africa.

\section{OPERATION FOR STRABISMUS WITH A HORSEHAIR LOOP.}

BY George Wherry, M.C. CAMB., F.R.C.S. ENG.

IN cases of internal squint, when one eye requires a considerable correction, I have tried the following method, which aroids an open wound and stitches in the conjunctiva, yet allows a free division of fascia above and below the tendon. A strabismus hook is required which has a round eyelet hole very near the point threaded with a long horsehair. A small opening with scissors and fixation forceps is made on to the sclerotic below the internal rectus and the threaded hook is passed behind the tendon. Another little opening is made above the tendon, or the projecting. point cut down upon, so that the horsehair can be pulled through ; the hook is then withdrawn, leaving the horsehair behind the tendon with a free end through the upper and lower wound. The unarmed hook is then passed, but in front of the tendon, from below upwards through the same openings, threaded with the horsehair which was left in the upper opening, and withdrawn. The tendon and all lower cuts is thus included in a loop of horsehair. This is pulled down gently, and the scissors cutting upwards through the fascia and capsule of Tenon between the upper and the lower opening readily divide all the included tissues until the loop is pulled completely through. The eyeball is rotated outwards and the seat of operation rubbed smooth. There is very little swelling or ecchymosis. Though Graefe open plan may be often best for extreme and Critchett's or Taylor's for ordinary cases, the operation described above may prove useful as an intermediate method.

Corpus-buildings, Cambridge.

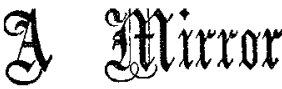

of

\section{HOSPITAL PRACTICE,} BRITISH AND FOREIGN.

Nulla autem est alia pro certo noscendi via, nisi quamplurimas et mor borum et dissectionum historias, tum aliorum tum proprias collectas habero, et inter se comparare.-MoRgaGi De Sed. et Caus. Mforb., haber $\theta$, et inter se
lib. iv. Procemium.

\section{MIDDLESEX HOSPITAL.}

AMPUTATION AT THE SHOULDER-JOINT FOR NECROSIS OF HUMERUS, - TORTUOSITY OF ARTERY SIMULATING ANEURYSM.

(Under the care of Mr. HulKe.)

This first case seems worthy of being recorded, if not on other grounds, as an illustration of recovery after exarticulation undertaken in very adverse circumstances. The relatively slight degree of pain, the early swelling of the whole limb and the tracts of induration, redness and tenderness along the course of the vessels in the upper arm appeared suggestive of phlebitis followed by cellulitis rather than to point to an acute osteo-myelitis. Epiphysitis was considered almost certainly excluded by the patient's age. It is certain that in the earlier stages the stress of the inflammation did not fall on the periosteum-in other words, that the disorder was not an acute diffuse periostitis, since at that time through none of the incisions (though these were sufficiently deep to have divided this membrane had it been raised by inflammatory products) conld denuded bone be detected. The condition, then, appears to have been an acute, initially central necrosis beginning near the proximal end, spreading thence down the interior of the shaft and entailing also suppuration of the shoulder-joint. Might this have originated in the breaking down of a caseated long-latent tuberculous depôt, in connexion with her greatly deteriorated health?

Amputation at the shoulder for extensive necrosis of the humerus; recovery. - A married woman aged thirty-six, the mother of two children, had for a long time been phthisical and was very weak and looked extremely ill when she was admitted into Bird Ward on June 13th, 1889. Her entire right upper limb, from the hand to the shoulder, was oedematously swollen. Over the bicipital groove, and outwards from this, the deltoid was raised by a distinctly fluctuating swelling. Limited passive movements of the shoulder were not painful, but any attempt to move the arm through a wider range caused great suffering. Along the inner side of the arm, ore the course of the brachial vessels, there was an indurated tract and a band of tissue at the outer side was also hard. The skin over these tracts was red and pressure here elicited pain. The cutaneous veins were very distended. She had diarrhoea and considerable fever. The patient, who had long 